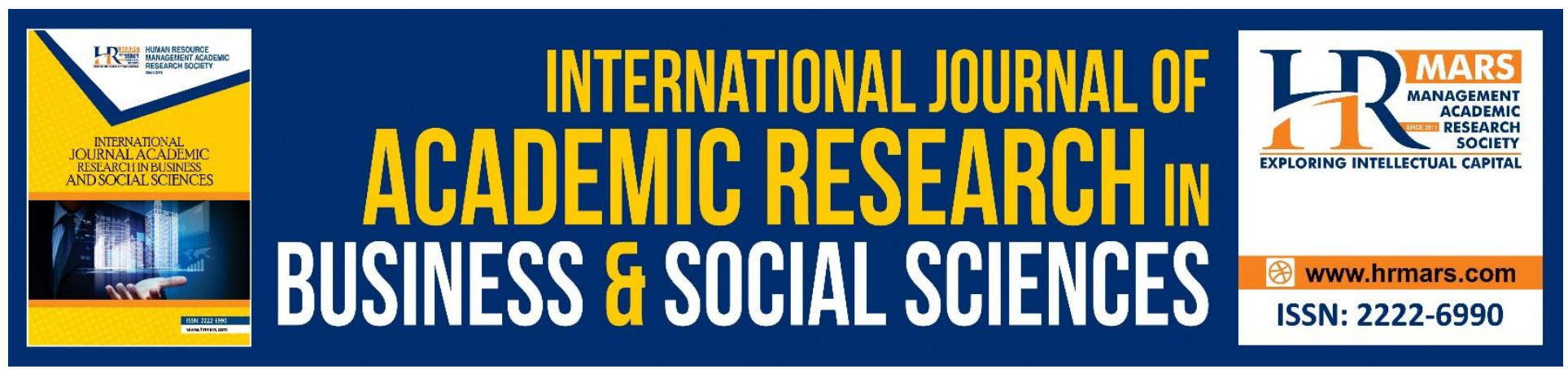

\title{
Demographic Determinants of Patient Satisfaction: A Study in a Turkish Context
}

\author{
Evren Ayranci, Nazmiye Atalay
}

To Link this Article: http://dx.doi.org/10.6007/IJARBSS/v9-i6/6041

DOI: $10.6007 /$ IJARBSS/v9-i6/6041

Received: 20 April 2019, Revised: 10 May 2019, Accepted: 07 June 2019

Published Online: 29 June 2019

In-Text Citation: (Ayranci \& Atalay, 2019)

To Cite this Article: Ayranci, E., \& Atalay, N. (2019). Demographic Determinants of Patient Satisfaction: A Study in a Turkish Context. International Journal of Academic Research in Business and Social Sciences, 9(6), 829-839.

Copyright: (C) 2019 The Author(s)

Published by Human Resource Management Academic Research Society (www.hrmars.com)

This article is published under the Creative Commons Attribution (CC BY 4.0) license. Anyone may reproduce, distribute, translate and create derivative works of this article (for both commercial and non-commercial purposes), subject to full attribution to the original publication and authors. The full terms of this license may be seen

at: http://creativecommons.org/licences/by/4.0/legalcode

Vol. 9, No. 6, 2019, Pg. $829-839$

http://hrmars.com/index.php/pages/detail/IJARBSS

JOURNAL HOMEPAGE

Full Terms \& Conditions of access and use can be found at http://hrmars.com/index.php/pages/detail/publication-ethics 


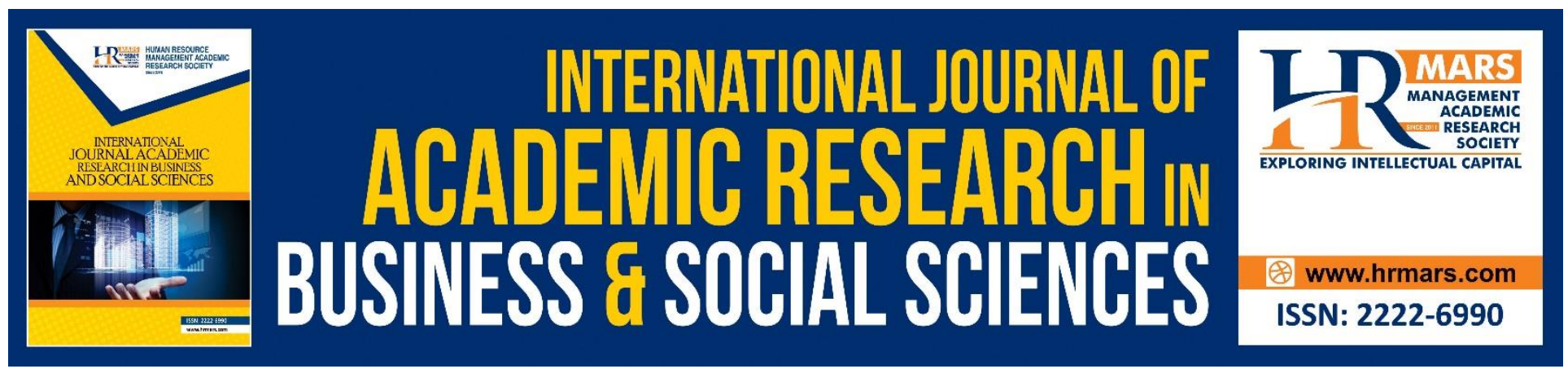

\title{
Demographic Determinants of Patient Satisfaction: A Study in a Turkish Context
}

\author{
Evren Ayranci ${ }^{1}$, Nazmiye Atalay ${ }^{2}$ \\ ${ }^{1}$ Istanbul Kultur University, Faculty of Economics and Administrative Sciences, Istanbul, Turkey. \\ ${ }^{2}$ Istanbul AREL University, Institute of Social Sciences, Istanbul, Turkey.
}

\begin{abstract}
Patient satisfaction is at the heart of all health care activities; and thus, it requires a special attention. Among various approaches to patient satisfaction, those using patients' demographics have very mixed results. An attempt for clarification is needed. For this reason, this study aims to scrutinize possible effects of patients' demographic features on their satisfaction. Data were collected from 372 participants who actively received health services from the clinics of eight private and public general hospitals in the city of istanbul. An inclusive approach is embraced in terms of covering as many factors of patient satisfaction as possible by means of combining various related instruments. After a unique satisfaction structure is obtained, the effects of patients' genders, ages, education levels, and marital statuses on this structure are examined. The results indicate that there is a partial effect of participants' demographic features on their satisfaction, which is solely limited to their ages and marital statuses.
\end{abstract}

Keywords: Patient Satisfaction, Demographics, Clinic, Hospital, Turkey

\section{Introduction}

Patient satisfaction is one of the most important health outcomes for the ultimate goal: increasing the quality and effectiveness of health care (Atinga et al. 2011). For this reason, patient satisfaction should not be considered as an outcome solely; it is also an input in the process of health service development.

This duality of patient satisfaction results in a vast scientific interest, and therefore, tremendous effort is present in the literature. Whereas most studies prefer to use the outcome perspective (e.g., Chow et al., 2009), some emphasize the input feature of satisfaction (e.g., Zastowny et al., 1989). A closer look at the outcome side reveals that relevant studies could be grouped bilaterally: those that investigate the contents and structure of patient satisfaction (Hagedoorn et al., 2003) and those that aim to understand the causes of patient satisfaction, along with the nature of these causes (Thompson and Sunol 1995).

This study focuses on the outcome side and seeks to make a contribution to both of the groups by bringing the scope and factors related to patient satisfaction into open and by analysing the 
relationships between satisfaction and possible causes. Interestingly, these causes could be further divided into two groups. While numerous studies facilitate health services to assess patient satisfaction by emphasizing health service experience (Isaac et al., 2010), very few studies dwell on patients' own features and claim that these features affect satisfaction (Hekkert et al. 2009). It is considered that addressing the lesser-treated own features could be a greater contribution; thus, these features are involved in the research. Finally, the discovery of many issues within these features motivates a choice, and some demographic features of patients are selected as possible determinants of their satisfaction.

It is believed that these contributions, in addition to providing compelling information from the Turkish context, are the distinctive attributes of this study.

\section{Patients' Demographics and Their Satisfaction}

The patient is the centre of everything in health care. Not only patients' health but also their contentment is taken into consideration. The outcome is a deep emphasis on patient satisfaction and, hence, a vast variety of studies that seek an understanding of the nature of this satisfaction.

This nature is subjected to two groups of research in the literature. While a subset of studies briefly highlights the antecedents of patient satisfaction within the definitions of patient satisfaction, another subset addresses how patient satisfaction is built and maintained. Examples of the former include defining patient satisfaction as patients' evaluations of the health services provided in terms of communication with health professionals and their qualifications (Ramsaran-Fowdar 2005); patients' contentment with the empathy and reliability of health staff during the health service process (Tucker and Adams 2001); and patients' appraisal of medical sufficiency, nursing quality, foods, hygiene, and paperwork (Woodside et al. 1989).

On the other hand, direct research on the factors related to patient satisfaction exhibits a twofold structure: it depends on individuals' demographics and anticipatory (Kravitz et al. 1996), perceptual (Cleary et al. 1991) and psycho-emotional (Greenley et al. 1982) states (own features), and it is shaped by social interactions within health institutions (Marple et al. 1997) in addition to these institutions' physical features (Hueston et al. 1996). As per the interest of this study, patients' demographics are in question.

An interesting outcome is that inspections of patients' demographics to understand their satisfaction reveal very mixed results when demographics are in question. Some studies conclude that there is no relationship between age and patient satisfaction (e.g., Ozbakir and Ergin 1997), whereas some prove that elderly patients are generally more satisfied than younger ones (Hall and Dornan 1990). The results regarding gender indicate a very similar outcome: In addition to the fact that males (Mohamed et al. 2015) or females (Butler et al. 1996) are more satisfied patients, there may not be any connection between patient satisfaction and gender at all (Marple et al. 1997). Despite the strong evidence that education level and patient satisfaction are interconnected, the nature of the relationship varies. Patients with a lower level of education are claimed to exaggerate the health services provided, and therefore, they state a higher level of satisfaction (Hall and Dornan 1990); in contrast, it is also evidenced that a higher level of education results in higher satisfaction (Yilmaz 2001). Marital status, moreover, poses variability; therefore, there is evidence that patients' 
INTERNATIONAL JOURNAL OF ACADEMIC RESEARCH IN BUSINESS AND SOCIAL SCIENCES

Vol. 9, No. 6, June, 2019, E-ISSN: 2222-6990 (C) 2019 HRMARS

marital status does not affect their satisfaction (Chen et al. 2016) and vice versa (Afzal et al. 2014). The existing effect usually pinpoints that married patients are more satisfied (Afzal et al. 2014).

\section{Research Methodology}

\section{Purpose, Scope, and Data Collection Approach}

This research aims to identify important factors related to two significant issues. One issue is the extent of patient satisfaction. In contrast to most similar studies, it is expected that factors of patient satisfaction could exhibit unique patterns and contents in the Turkish context. Therefore, it was decided to embrace a multilateral and original approach using a combination of many patient satisfaction instruments. The other issue is the main aim of determining how patient satisfaction differs due to specific demographic features of patients.

These issues are investigated via data collected from eight private and public general hospitals in the city of istanbul. Due to greater ease of access and more participation opportunities, participants are limited to patients who are getting health services from any of the hospitals' clinics. The population, in this case, consists of 11,362 patients, as denoted in accessible hospitals' records; the sample size is calculated to be 372 , while the confidence level is $95 \%$ and the margin of error is $5 \%$ (Raosoft 2004). Through the use of simple random sampling in all eight hospitals, 372 participants were reached.

Data are collected using bipartite questionnaires. While the first part is related to participants' demographic features, the second part is interested in patient satisfaction in terms of evaluations of the hospital context and social interactions. Patient satisfaction is measured by a combination of instruments, which are also validated and used in Turkish health research cases. These include scales used by Tufekci and Asigbulmus (2016), Atilla (2012), and Karaalp (2014).

\section{Patient Satisfaction Structure}

An investigation of patient satisfaction reveals that it is actually a multidimensional construct (Table 1), consisting of the hospital context, doctors' behaviours, and health personnel's behaviours. This tripartite structure can aggregately explain $62.152 \%$ of the total variance and is reliable at the factor and overall levels, as denoted in Table 1. 
INTERNATIONAL JOURNAL OF ACADEMIC RESEARCH IN BUSINESS AND SOCIAL SCIENCES Vol. 9, No. 6, June, 2019, E-ISSN: 2222-6990 @ 2019 HRMARS

Table 1. Exploratory Factor and Reliability Analyses of Patient Satisfaction Construct

\begin{tabular}{|c|c|c|c|}
\hline \multicolumn{4}{|c|}{ KMO Value: 0.790 (Bartlett's test value is statistically significant) } \\
\hline & $\begin{array}{l}\text { Doctors' } \\
\text { Behaviour } \\
\text { s }\end{array}$ & $\begin{array}{l}\text { Hospital } \\
\text { Context }\end{array}$ & $\begin{array}{l}\text { Health } \\
\text { Personnel' } \\
\text { S } \\
\text { Behaviour }\end{array}$ \\
\hline Variance Explained (\%) & 23.681 & 21.434 & 17.037 \\
\hline Cronbach's Alpha Value & 0.891 & 0.822 & 0.783 \\
\hline Overall Cronbach's Alpha Value & \multicolumn{3}{|l|}{0.703} \\
\hline My doctor acted timely for the first examination. & 0.879 & & \\
\hline My doctor used a very understandable way of speaking. & 0.851 & & \\
\hline My doctor spoke to me very gently. & 0.847 & & \\
\hline I could ask as many questions as I wanted to my doctor. & 0.811 & & \\
\hline $\begin{array}{l}\text { My doctor gave me further recommendations regarding } \\
\text { my problem. }\end{array}$ & 0.752 & & \\
\hline The polyclinics were hygienic and properly designed. & & 0.821 & \\
\hline $\begin{array}{l}\text { It was easy to find what I was looking for in the hospital } \\
\text { huildins }\end{array}$ & & 0.813 & \\
\hline The toilets were hygienic. & & 0.801 & \\
\hline There were enough and understandable guidance signs. & & 0.795 & \\
\hline The car parking and recreation facilities were adequate. & & 0.642 & \\
\hline The departments were adequately heated and lighted. & & 0.628 & \\
\hline $\begin{array}{l}\text { The nurses provided enough caring and they were } \\
\text { resnonsive }\end{array}$ & & & 0.872 \\
\hline $\begin{array}{l}\text { The health technicians provided enough caring and they } \\
\text { were responsive. }\end{array}$ & & & 0.834 \\
\hline $\begin{array}{l}\text { The health clerks provided enough caring and they were } \\
\text { responsive. }\end{array}$ & & & 0.700 \\
\hline $\begin{array}{l}\text { All health staff were affirmative in terms of their speech } \\
\text { and approach. }\end{array}$ & & & 0.687 \\
\hline $\begin{array}{l}\text { Extraction method: Principal component analysis. } \\
\text { Rotation method: Varimax with Kaiser normalization. } \\
\text { Factor loadings less than }|0.5| \text { are omitted. }\end{array}$ & & & \\
\hline
\end{tabular}

The structure that emerged from Table 1 shows that patients primarily consider their doctors' behaviours regarding their contentment. These involve proper timing, informing, meaningful communication, and professional recommendations. A second part of patient satisfaction pertains to hospital context, such as proper layout, guidance, parking, heating and lighting, and hygiene. The last satisfaction component addresses the behaviours of health personnel, such as their courteousness and caring, along with their affirmativeness. 
INTERNATIONAL JOURNAL OF ACADEMIC RESEARCH IN BUSINESS AND SOCIAL SCIENCES

Vol. 9, No. 6, June, 2019, E-ISSN: 2222-6990 @ 2019 HRMARS

\section{Effects of Demographic Features on Patient Satisfaction}

The next step is to consider the second and the main issue - to determine whether and how patient satisfaction varies when demographic features (gender, age, education level, and marital status) are in question.

This aim necessitates selection among possible analysis methods. An important point is the possibility of not having a normal distribution, which could signal the need for a non-parametric approach (such as Mann-Whitney $U$ and Kruskal-Wallis tests) rather than a parametric method (such as t-tests and ANOVA). According to Table 2, the normality tests on the data regarding patient satisfaction indicate a violation of the normal distribution and therefore an obligation to use nonparametric methods.

Table 2. Normality Tests on Patient Satisfaction Data

\begin{tabular}{|l|l|l|l|l|}
\hline Normality Tests & \multicolumn{2}{l|}{$\begin{array}{l}\text { Kolmogorov- } \\
\text { Smirnov }\end{array}$} & \multicolumn{2}{l|}{ Shapiro-Wilk } \\
\hline & Statistic & $p$ & $\begin{array}{l}\text { Statisti } \\
c\end{array}$ & $p$ \\
\hline All Items & 0.222 & 0.000 & 0.835 & 0.000 \\
\hline Health Personnel's Behaviours & 0.264 & 0.000 & 0.823 & 0.000 \\
\hline Hospital Context & 0.216 & 0.000 & 0.842 & 0.000 \\
\hline Doctors' Behaviours & 0.196 & 0.000 & 0.868 & 0.000 \\
\hline
\end{tabular}

Demographic features of participants involve four main issues, and the first analysis starts with gender. Therefore, the aim is to determine whether patient satisfaction varies when gender is in question. The results are given in Table 3.

Table 3. Patient Satisfaction Due to Gender

\begin{tabular}{|c|c|c|c|c|c|c|c|c|}
\hline $\begin{array}{l}\text { Patient } \\
\text { Satisfaction } \\
\text { Factors }\end{array}$ & $\begin{array}{l}\text { Categorie } \\
\text { s }\end{array}$ & $\mathbf{N}$ & Mean & SD & Median & $\begin{array}{l}\text { Mean } \\
\text { Rank }\end{array}$ & $\begin{array}{l}\text { Mann- } \\
\text { Whitney } \\
\text { U }\end{array}$ & $\mathbf{p}$ \\
\hline \multirow{2}{*}{ Overall } & Female & 217 & 105.3 & 12.7 & 108 & 188.36 & \multirow{2}{*}{15.452} & \multirow{2}{*}{$\begin{array}{l}0.28 \\
3\end{array}$} \\
\hline & Male & 155 & 104.8 & 12.5 & 107 & 175.83 & & \\
\hline \multirow{2}{*}{$\begin{array}{l}\text { Health } \\
\text { Personnel's } \\
\text { Behaviours }\end{array}$} & Female & 217 & 19.2 & 3.3 & 17 & 184.67 & \multirow[b]{2}{*}{16.618} & \multirow{2}{*}{$\begin{array}{l}0.87 \\
6\end{array}$} \\
\hline & Male & 155 & 18.4 & 3.2 & 16 & 183.12 & & \\
\hline \multirow{2}{*}{ Hospital Context } & Female & 217 & 28.2 & 5.1 & 27 & 185.46 & \multirow{2}{*}{16.137} & \multirow{2}{*}{$\begin{array}{l}0.76 \\
8 \\
\end{array}$} \\
\hline & Male & 155 & 27.9 & 5.3 & 28 & 181.77 & & \\
\hline \multirow{2}{*}{$\begin{array}{l}\text { Doctors' } \\
\text { Behaviours }\end{array}$} & Female & 217 & 21.6 & 3.6 & 23 & 190.41 & \multirow{2}{*}{15.211} & \multirow{2}{*}{$\begin{array}{l}0.16 \\
7\end{array}$} \\
\hline & Male & 155 & 20.9 & 3.6 & 22 & 176.52 & & \\
\hline
\end{tabular}

As per Table 3, an interesting outcome is the closeness of means between genders whether patient satisfaction is considered as a whole or whether each factor of satisfaction is examined distinctively. A statistically significant difference, however, is not possible for any case. A very clear 
INTERNATIONAL JOURNAL OF ACADEMIC RESEARCH IN BUSINESS AND SOCIAL SCIENCES Vol. 9, No. 6, June, 2019, E-ISSN: 2222-6990 (C) 2019 HRMARS

finding, in this sense, is that patient satisfaction and its distinct factors are not subject to change across genders.

Table 4 involves the results for the connection between age and patient satisfaction. Age is proxied by five different age groups in the questionnaires.

Table 4. Patient Satisfaction Due to Age Groups

\begin{tabular}{|c|c|c|c|c|c|c|c|c|c|c|}
\hline Item & $\begin{array}{l}\text { Categorie } \\
\mathrm{s}\end{array}$ & $\mathbf{N}$ & Mean & SD & Median & $\begin{array}{l}\text { Mean } \\
\text { Rank }\end{array}$ & $\begin{array}{l}\text { Kruska } \\
\text { Wallis } \\
\left(x^{2}\right)\end{array}$ & ) & $\begin{array}{l}\text { Post } \\
\text { Hoc }\end{array}$ & p \\
\hline \multirow{5}{*}{ Age } & $18-25$ (a) & 46 & 97.6 & 12.8 & 100 & 124.97 & \multirow{5}{*}{24.86} & \multirow{5}{*}{$\begin{array}{l}<0.00 \\
1\end{array}$} & $(a)<$ (b) & 0.013 \\
\hline & $26-35$ (b) & 100 & 105.9 & 11.5 & 108 & 185.22 & & & (a) < (c) & 0.009 \\
\hline & $36-45$ (c) & 114 & 106.2 & 11.2 & 106 & 184.17 & & & (a) $<$ (d) & 0.002 \\
\hline & $46-55(d)$ & 78 & 107.3 & 13.4 & 111 & 201.24 & & & (a) $<$ (e) & $<0.001$ \\
\hline & $\begin{array}{l}56 \text { and } \\
\text { older (e) }\end{array}$ & 34 & 112.1 & 3.7 & 112 & 236.08 & & & & \\
\hline
\end{tabular}

An immediate result from Table 4 is that patient satisfaction varies by the age groups considered $\left(\chi^{2}(4)=24.86 ; p<0.001\right)$. In other words, being in different age groups affects patient satisfaction. The post hoc tests indicate a significant difference between the 18-25 age group and the other age groups, and that patients in this group are less satisfied than the rest of the older-aged groups $\left(\overline{\mathrm{x}}_{18-25}=97.6\right)$.

The next table, Table 5, signifies that patients' level of education does not affect their satisfaction; that is, there is no difference in patient satisfaction across different levels of education $\left(\chi^{2}(5)=2.88 ; p=0.743\right)$.

Table 5. Patient Satisfaction Due to Education Levels

\begin{tabular}{|c|c|c|c|c|c|c|c|}
\hline Item & Categories & $\mathbf{N}$ & Mean & SD & Median & $\begin{array}{l}\text { Kruskal- } \\
\text { Wallis } \\
\left(\chi^{2}\right)\end{array}$ & $\mathbf{p}$ \\
\hline \multirow{6}{*}{$\begin{array}{l}\text { Education } \\
\text { Level }\end{array}$} & Illiterate (a) & 17 & 106.28 & 13.227 & 110 & \multirow{6}{*}{2.88} & \multirow{6}{*}{0.743} \\
\hline & Primary Education (b) & 116 & 107.13 & 12.302 & 106.5 & & \\
\hline & High School (c) & 163 & 105.88 & 12.298 & 105 & & \\
\hline & Associate Degree (d) & 24 & 106.87 & 10.972 & 107 & & \\
\hline & Undergraduate (e) & 42 & 104.21 & 15.126 & 105.5 & & \\
\hline & Master's Degree (f) & 10 & 102.75 & 19.213 & 109.5 & & \\
\hline
\end{tabular}

Marital status has four categories in the questionnaires: single, married, divorced, and living with a partner. An investigation of marital status in terms of patient satisfaction in Table 6 shows a significant overall effect, in addition to an intriguing result. 
INTERNATIONAL JOURNAL OF ACADEMIC RESEARCH IN BUSINESS AND SOCIAL SCIENCES Vol. 9, No. 6, June, 2019, E-ISSN: 2222-6990 @ 2019 HRMARS

Table 6. Patient Satisfaction Due to Marital Status

\begin{tabular}{|c|c|c|c|c|c|c|c|c|c|c|}
\hline Item & Categories & $\mathbf{N}$ & $\begin{array}{l}\text { Mea } \\
\mathrm{n}\end{array}$ & $\begin{array}{l}\text { S } \\
\text { D }\end{array}$ & $\begin{array}{l}\text { Media } \\
n\end{array}$ & $\begin{array}{l}\text { Mean } \\
\text { Rank }\end{array}$ & $\begin{array}{l}\text { Kruska } \\
\text { l- } \\
\text { Wallis } \\
\left(x^{2}\right)\end{array}$ & p & Post Hoc & $\mathbf{p}$ \\
\hline \multirow{4}{*}{$\begin{array}{l}\text { Marital } \\
\text { Status }\end{array}$} & Single (a) & 36 & 102.8 & 2 & 105 & 154.43 & \multirow{4}{*}{18.37} & \multirow{4}{*}{0.001} & \multirow[b]{2}{*}{$a<b$} & \multirow{2}{*}{$\begin{array}{l}0.00 \\
9\end{array}$} \\
\hline & Married (b) & 312 & 108.1 & 3 & 108 & 188.39 & & & & \\
\hline & Divorced (c) & 20 & 105.9 & 5 & 110.5 & 184.24 & & & \multirow{2}{*}{$d<b$} & \multirow{2}{*}{$\begin{array}{l}0.02 \\
2\end{array}$} \\
\hline & $\begin{array}{l}\text { Living with a } \\
\text { Partner }(\mathrm{d})\end{array}$ & 4 & 83.22 & 0 & 85.5 & 42.52 & & & & \\
\hline
\end{tabular}

According to Table 6, patient satisfaction shows changes when marital status is examined $\left(\chi^{2}(3)=18.37 ; p=0.001\right)$. A closer look at post hoc tests reveals that the difference between married patients' ( $\left.\bar{x}_{\text {married }}=108.1\right)$ and single patients' $\left(\bar{x}_{\text {single }}=102.8\right)$ satisfaction is statistically significant, similar to the case in which the satisfaction changes between married patients and those living with a partner $\left(\bar{x}_{\text {living with a partner }}=83.22\right)$. A general conclusion is that married patients are more satisfied in comparison to others.

\section{Conclusions and Suggestions}

This study considers a relatively less subjective issue, namely, patients' demographic features, instead of addressing their health service experience, which is widely used when the effects on patient satisfaction are scrutinized. The result of this choice reflects a harmony with the literature: there are partial effects of patients' demographic features on their satisfaction. Whereas age and marital status can affect patient satisfaction, other factors, including gender, and education level fail to pose any impact.

A comparison with similar studies in terms of age reveals that the same result is achieved when age is found to affect satisfaction; older patients are more satisfied than younger patients. When marital status is in question, an emerging outcome is that in addition to its effects on satisfaction, married patients are more satisfied than others. These findings are also parallel to results achieved in the literature.

Another result is related to the structure of the patient satisfaction construct; it partially involves social interactions in the hospital context and refers to the behaviours of health personnel and doctors. Features of the hospitals, such as layout, parking facilities, lighting, and heating, are also accounted for. This outcome applies to both groups of studies described: those defining patient satisfaction and those scrutinizing causes of this satisfaction. In other words, the three extracted patient satisfaction factors are simultaneously considered within some definitions of patient satisfaction, and they are moreover perceived to be causes of this satisfaction.

It is considered that some suggestions could be convenient as of this point. This study solely considers demographic features of the patients when their satisfaction is in question. This approach 
could be broadened by considering other personal features such as patients' personality traits or their attitudes regarding their health service experience in order to reach to a more inclusive and peripheral conclusion. The findings of this study also suggest that doctors should be distinctively considered in terms of patient satisfaction; and thus, there should be separate attention paid to doctors and other health personnel. Another suggestion is similar to this distinctive approach; it is revealed that some demographic features are effective on the patient satisfaction and this outcome clearly posits that the demographic features cannot be considered to affect the patient satisfaction aggregately. Future studies could investigate this issue to account for differences among distinctive demographic features' effects.

As noticed, these suggestions are towards scientific purposes and they must be accompanied by suggestions regarding practicability. Hospitals should focus on the behaviours of their doctors and other health personnel and they should perform orientations that aim to enhance these members' communication with the patients. Partial effects of demographic features give rise to the consideration that hospitals should pay attention to each demographic feature of the patients and provide customized approaches based on each specific feature in order to maximize patient satisfaction.

This study contributes to the literature in terms of uniqueness and suggestions. The uniqueness depends on the facts that the patient satisfaction structure is original; the effect tested is study-specific and involves this original structure; and unlike the most of other similar studies, many demographic features of patients are considered simultaneously within this effect. The majority of suggestions made are believed to be important and unmatched, due to the facts that many of them have not been fully considered in the previous research in general and they provide a great chance to make further and more advanced studies in the future.

\section{References}

Afzal, M., Rizvi, F., Azad, A. H., Rajput, A. M., Khan, A., \& Tariq, N. (2014). Effect of Demographic Characteristics on Patient's Satisfaction with Health Care Facility. Journal of Postgraduate Medical Institute, 28(2), 154-160.

Atilla, G. (2012). The Relation between Emotional Intelligence and Patient Satisfaction in Hospitals: Isparta Province Example. Doctoral Dissertation, Suleyman Demirel University, Isparta, Turkey.

Atinga, R. A., Abekah-Nkrumah, G., \& Domfeh, K. A. (2011). Managing Healthcare Quality in Ghana: A Necessity of Patient Satisfaction. International Journal of Health Care Quality Assurance, 24(7), 548-563.

Butler, D., Oswald, S. L., \& Turner, D. E. (1996). The Effects of Demographics on Determinants of Perceived Health-Care Service Quality: The Case of Users and Observers. Journal of Management in Medicine, 10(5), 8-20.

Chen, H., Li, M., Wang, J., Xue, C., Ding, T., Nong, X., et al (2016). Factors Influencing Inpatients' Satisfaction with Hospitalization Service in Public Hospitals in Shanghai, People's Republic of China. Patient Preference and Adherence, 10, 469-477.

Chow, A., Mayer, E. K., Darzi, A. W., \& Athanasiou, T. (2009). Patient-Reported Outcome Measures: The Importance of Patient Satisfaction in Surgery. Surgery, 146(3), 435-443. 
INTERNATIONAL JOURNAL OF ACADEMIC RESEARCH IN BUSINESS AND SOCIAL SCIENCES

Vol. 9, No. 6, June, 2019, E-ISSN: 2222-6990 @ 2019 HRMARS

Cleary, P. D., Edgman-Levitan, S., Roberts, M., Moloney, T. W., McMullen, W., Walker, J. D., et al. (1991). Patients Evaluate their Hospital Care: A National Survey. Health Affairs, 10(4), 254267.

Greenley, J. R., Young, T. B., \& Schoenherr, R. A. (1982). Psychological Distress and Patient Satisfaction. Medical Care, 20(4), 373-385.

Hagedoorn, M., Uijl, S. G., Van Sonderen, E., Ranchor, A. V., Brigit, M. F. G., Otter, R., et al. (2003). Structure and Reliability of Ware's Patient Satisfaction Questionnaire III: Patients' Satisfaction with Oncological Care in The Netherlands. Medical Care, 41(2), 254-263.

Hall, J. A., \& Dornan, M. C. (1990). Patient Sociodemographic Characteristics as Predictors of Satisfaction with Medical Care: A Meta-Analysis. Social Science \& Medicine, 30(7), 811-818.

Hekkert, K. D., Cihangir, S., Kleefstra, S. M., Van den Berg, B., \& Kool, R. B. (2009). Patient Satisfaction Revisited: A Multilevel Approach. Social Science \& Medicine, 69(1), 68-75.

Hueston, W. J., Mainous, A. G., \& Schilling, R. (1996). Patients with Personality Disorders: Functional Status, Health Care Utilization, and Satisfaction with Care. The Journal of Family Practice, 42(1), 54-60.

Isaac, T., Zaslavsky, A. M., Cleary, P. D., \& Landon, B. E. (2010). The Relationship between Patients' Perception of Care and Measures of Hospital Quality and Safety. Health Services Research, 45(4), 1024-1040.

Karaalp, T. (2014). Effects of Physical Environment on Patient Satisfaction and Job Satisfaction in the Delivery of Health Services. Doctoral Dissertation, Gulhane Military Medicine Academy, Ankara, Turkey.

Kravitz, R. L., Callahan, E. J., Paterniti, D., Antonius, D., Dunham, M., \& Lewis, C. E. (1996). Prevalence and Sources of Patients' Unmet Expectations for Care. Annals of Internal Medicine, 125(9), 730-737.

Marple, R. L., Kroenke, K., Lucey, C. R., Wilder, J., \& Lucas, C. A. (1997). Concerns and Expectations in Patients Presenting with Physical Complaints: Frequency, Physician Perceptions and Actions, and 2-Week Outcome. Archives of Internal Medicine, 157(13), 1482-1488.

Mohamed, E. Y., Sami, W., Alotaibi, A., Alfarag, A., Almutairi, A., \& Alanzi, F. (2015). Patients' Satisfaction with Primary Health Care Centers' Services, Majmaah, Kingdom of Saudi of Saudi Arabia. International Journal of Health Sciences, 9(2), 163-170.

Ozbakir, D., \& Ergin, C. (1997). A patient contentment study in first level health services, In D. Ozbakir \& C. Ergin (Eds.), Total Quality Management and Performance Measurement in Health Services (pp. 113-118). Ankara, Turkey: Haberal Education Fund Publications.

Ramsaran-Fowdar, R. R. (2005). Identifying Health Care Quality Attributes. Journal of Health and Human Services Administration, 27(4), 428-443.

Raosoft. (2004). Sample Size Calculator. Retrieved from http://www.raosoft.com/samplesize.html.

Thompson, A. G. H., \& Sunol, R. (1995). Expectations as Determinants of Patient Satisfaction: Concepts, Theory and Evidence. International Journal for Quality in Health Care, 7(2), 127141.

Tucker, J. L., \& Adams, S. R. (2001). Incorporating Patients' Assessments of Satisfaction and Quality: An Integrative Model of Patients' Evaluations of their Care. Managing Service Quality: An International Journal, 11(4), 272-287. 
Tufekci, N., \& Asigbulmus, H. (2016). The Factors that Effective in the Choice of Hospital and Patient Satisfaction: The Sample of Isparta. Journal of Current Researches on Health Sector, 6(2), 7292.

Woodside, A. G., Frey, L. L., \& Daly, R. T. (1989). Linking Service Quality, Customer Satisfaction, and Behavioral Intention. Journal of Health Care Marketing, 9(4), 5-17.

Yilmaz, M. (2001). Patient Satisfaction: A Criteria of Health Care Quality. Cumhuriyet Nursing Journal, $5(2), 69-74$.

Zastowny, T. R., Roghmann, K. J., \& Cafferata, G. L. (1989). Patient Satisfaction and the Use of Health Services: Explorations in Causality. Medical Care, 27(7), 705-723.

\section{Corresponding Author}

Evren AYRANCI

E-mail: e.ayranci@iku.edu.tr 